\title{
Investigation on tsunami effects in the central Adriatic Sea during the last century - a contribution
}

\author{
A. Maramai ${ }^{1}$, L. Graziani ${ }^{1}$, and S. Tinti ${ }^{2}$ \\ ${ }^{1}$ Istituto Nazionale di Geofisica e Vulcanologia, Sezione Roma 2, Rome, Italy \\ ${ }^{2}$ University of Bologna, Dipartimento di Fisica, Settore Geofisica, Bologna, Italy
}

Received: 28 September 2006 - Revised: 13 December 2006 - Accepted: 13 December 2006 - Published: 10 January 2007

\begin{abstract}
In this work we present the result of a study aimed at examining the Italian earthquake sequences that occurred in the area of the central Adriatic sea with the purpose of understanding whether some of them were accompanied by tsunami effects. The motivation for this research was the update and enrichment of the Italian Tsunami Catalogue. The result was that evidence was found for two new cases of earthquake-induced tsunamis: these are the August $1916 \mathrm{Ri}-$ mini and the October 1930 Ancona events.

The bulk of the present research consisted in collecting all the available data on the earthquakes that affected the selected area in the past century and in identifying those potentially capable of generating tsunamis. During the study all the available material was gathered, which includes specific monographs and scientific papers, articles available in contemporary chronicles and in local and national newspapers. The final result of this research will improve our knowledge of the tsunamigenic activity of the central Adriatic sea and contribute to the assessment of the tsunami hazard and risk along these coasts, that especially in the peak season form one of the most densely populated areas of the Italian peninsula with flat and large beaches and water front resorts crowded of tourists.
\end{abstract}

\section{Introduction}

In the frame of the geophysical knowledge of the Mediterranean region the geodynamic evolution of the Adriatic microplate, very complex and still debated, plays a key role. Many international studies have been carried out with the aim of better assessing the seismicity of this region (Bada et al., 1996; Babbucci et al., 2004; Battaglia et al., 2004; Venisti et al., 2005; Pinter and Grenerczy, 2006; Altiner et al., 2006;

Correspondence to: A. Maramai

(maramai@ingv.it)
Thouvenot and Fréchet, 2006; Muço, 2006). They put in evidence that the Adriatic sea presents a quite low seismic activity, mainly with intraplate earthquakes characterised by moderate magnitudes. Earthquakes catalogues show large uncertainties in the hypocentre locations and in the magnitude estimates: the historical seismicity is poorly documented and, in particular, one of the major difficulties is to establish if an earthquake occurred in the Adriatic sea or inland. Similarly, instrumental seismicity shows mislocations probably due to badly spaced recording stations. In the last decades, significant seismicity has been noticed in this area, with important seismic sequences having main shocks of relevant magnitude.

The most recent Italian Tsunami Catalogue (Tinti et al., 2004), spanning from $79 \mathrm{AD}$ to 2004, contains a number of tsunamis observed along the Adriatic coasts which can be put in relation to the earthquake activity. In the catalogue each event is characterised by a "reliability" value, a very important parameter which expresses the quality of the data, and by a tsunami "intensity" value. The reliability is graded according to the 5-degree modified Iida scale (Iida, 1956) and ranges from degree 0 , equivalent to a "very improbable tsunami", to degree 4 corresponding to a "definite tsunami". The tsunami intensity value is attributed on the basis of the effects of a tsunami on structures and environment and it is based on the Sieberg-Ambraseys scale (Ambraseys, 1962).

The total number of tsunami events reported in the Italian Tsunami Catalogue for the central Adriatic region is 8 (Fig. 1), most of them of low intensity (intensity 2 "light" on the Ambraseys-Sieberg scale) and one reaching intensity 5 ("very strong") that is the 30 July 1627 Gargano event. The catalogue divided the Adriatic region into four subregions, namely North Adriatic, in which one tsunami occurred, central Adriatic, with 3 events and Gargano and Apulia, both affected by 2 tsunamis. All of them, except one, are of seismic origin.

Published by Copernicus GmbH on behalf of the European Geosciences Union. 


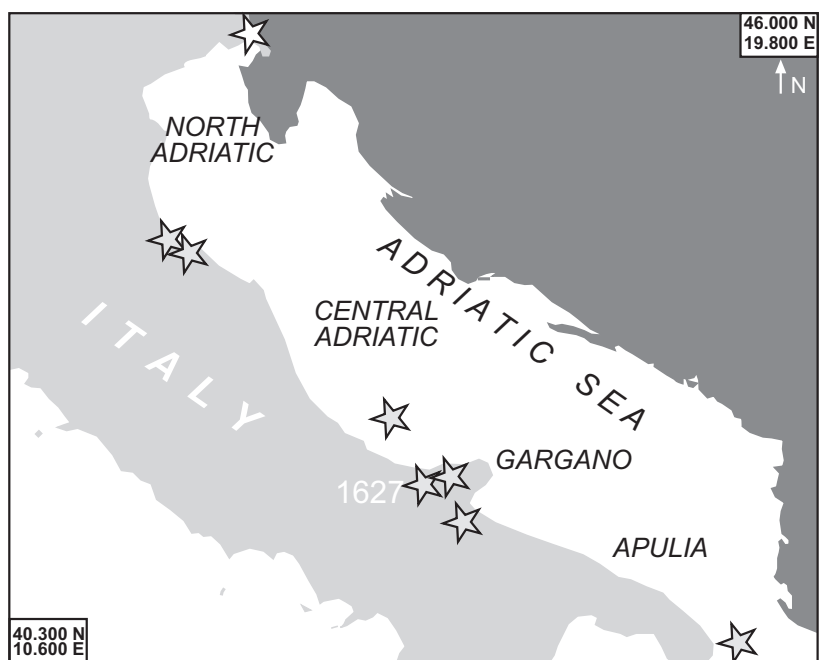

Fig. 1. Geographic distribution of tsunamis in the Adriatic Sea (after the Italian tsunami catalogue, Tinti et al., 2004). Stars represent tsunami sources. Note that the 1978 tsunami source north of Gargano is still uncertain and is taken here from Bedosti (1980). The four subregions are shown.

In this work we focus on the central Adriatic subregion, in order to perform a deep investigation of the area, also finalised to update the Italian Tsunami Catalogue. The most relevant earthquakes that occurred in the last century have been analysed, with the aim of establishing whether they could have been accompanied by tsunamis. To accomplish this goal, we gathered all suitable documents available in contemporary chronicles, in local and national newspapers as well as in specific monographs and scientific articles.

\section{Italian Tsunami Catalogue: tsunami events in central Adriatic}

As mentioned before, the Italian Tsunami Catalogue (Tinti et al., 2004) reports that the central Adriatic subregion experienced three tsunami events, two of them of seismic origin and the third one of uncertain cause, probably due to a submarine landslide. Here a short description of the events is given.

The first tsunami of the area occurred on 14 April 1672 when a strong earthquake caused severe damage and many fatalities (some sources report 200, some others more than 500). The earthquake, with equivalent magnitude $\mathrm{Me}=5.7$ (Me is deduced from macroseismic data. For the definition of Me, refer to CFTI, 2004) and I=VIII Mercalli Cancani Sieberg (MCS) scale, was located in land a few kilometres far from Rimini (Fig. 2). According to the coeval descriptions, at Rimini the sea withdrew and then flooded the coast by about 20 paces $(15 \mathrm{~m})$ and some fishermen, that were in the sea close to the Rimini coast, observed an unusual strong sea

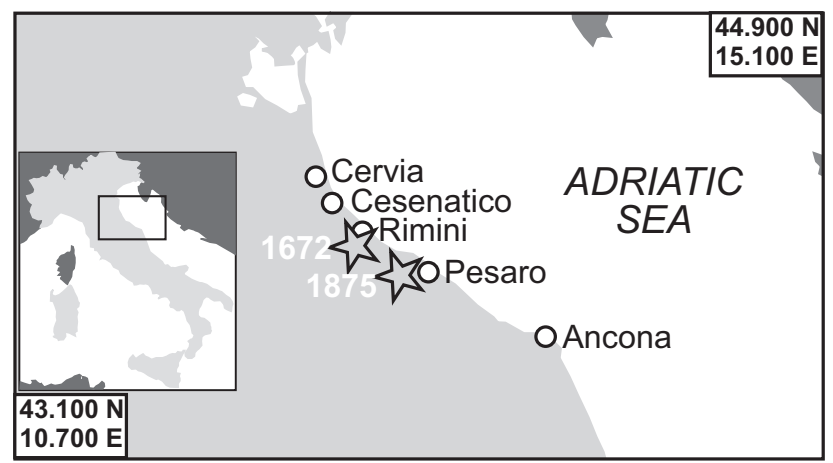

Fig. 2. Localities affected by the 1672 and 1875 Adriatic tsunamis. Stars represent the epicentres of the two tsunamigenic earthquakes.

agitation (Boschi et al., 1997; Tinti et al., 2004). The tsunami intensity attributed in the catalogue is 2 .

On 17 March 1875 another tsunami hit the central Adriatic area after a strong earthquake $(\mathrm{Me}=5.8$ (CFTI, 2004), I=VIII MCS scale) with epicenter in the sea close to Rimini, involving central Italy and part of northern Italy. The shock was very violent at Cesenatico, Rimini and Cervia (Fig. 2), where many chimneys ruined and some houses suffered damage. At Rimini some fishermen in boats felt a violent horizontal shock and noted some big waves. In the harbour the sea level was at a high tide, passed suddenly to a low tide returning to high tide again 2 min later. At Cervia the sea violently flooded quite a large part of the beach and some sailors felt the shock on the boats. At Cesenatico some big waves flooded the beach. At Pesaro eye-witnesses on the beach were reached by two big waves up to the waistband. At Ancona eye-witness report of some big waves (Tinti et al., 2004). The intensity attributed to this event by the Italian catalogue is 3 ("rather strong").

A third tsunami event occurred on 21 June 1978: anomalous coastal oscillations of the sea, with a period of about $10-15 \mathrm{~min}$, were observed along a $300 \mathrm{~km}$ stretch of coasts in the central Adriatic, between Giulianova and Bari (Fig. 3). No earthquake was recorded in that day to justify the anomalous event. Bedosti (1980) hypothesises that a possible cause was a submarine landslide beneath the $200 \mathrm{~m}$ isobath more or less between Termoli and Vasto (see star in Fig. 3). We remark that in the Italian Tsunami Catalogue this event was attributed an unknown cause, and we still persist in this position since new investigation is needed to unveil the real cause. We remark, however, that if the tsunami was induced by a submarine landslide, the source can very unlikely be located in the place suggested by Bedosti (1980) so close to the coast. Recent investigations show that this area is not susceptible to large offshore mass failures (Trincardi et al., 2004), while evidence for widespread failures has been found in the south-western Adriatic margin (Minisini et al., 2006) more than $100 \mathrm{~km}$ offshore south of Gargano, where steep slopes link the shallow Adriatic platform to the deep Ionian sea. 


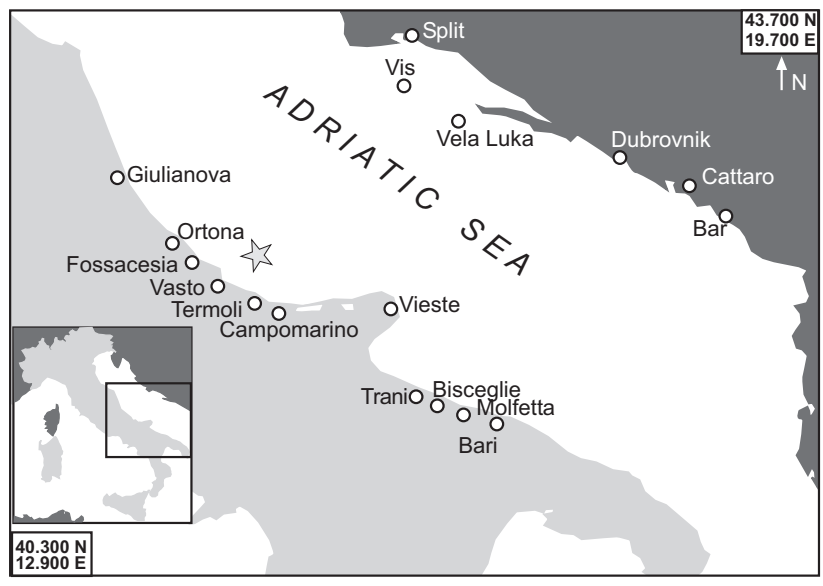

Fig. 3. Localities where tsunami effects were observed during the 1978 Adriatic event. The star represents the position of the submarine landslide hypothesised by Bedosti (1980), which is still under debate.

At Giulianova the sea withdrew by about $50 \mathrm{~m}$ and it came back $6 \mathrm{~min}$ later surpassing the normal level by about $60 \mathrm{~cm}$. Oscillations repeated many times with period of $15 \mathrm{~min}$ and amplitude of $60 \mathrm{~cm}$ in the harbour. At Ortona only one oscillation was observed, with a withdrawal of $15 \mathrm{~m}$. At Bisceglie the sea withdrew by $2-3 \mathrm{~m}$ and then flooded the beach by $200 \mathrm{~m}$. The maximum height was $50 \mathrm{~cm}$. Two fishing boats broke their mooring. At Molfetta a $10 \mathrm{~m}$ withdrawal was noticed. The period was $5 \mathrm{~min}$. Anomalous oscillations also were observed at Fossacesia, Vasto, Termoli, Campomarino and Trani at different times.

Anomalous disturbances were also seen on the eastern coast of the Adriatic Sea: at Bar $(30 \mathrm{~cm})$, Dubrovnik $(40 \mathrm{~cm})$ and Split $(45 \mathrm{~cm})$ (Zoe-Armanda, 1988; Papadopoulos, 1993).

Some newspapers report detailed description of the phenomenon, as follows. At Termoli the sea withdrew by tens of metres leaving the harbour dried and then violently came back; some swimmers referred that the sea water suddenly became cold and immediately after became also turbolent and strongly agitated (Il Messaggero, 1978) At Bari the sea water suddenly withdrew many times leaving the seafloor dried; some moored ships in the harbour went aground and some fish was found on the beach. At Bari and Vieste the sea suddenly withdrew by about $50-100 \mathrm{~m}$ leaving boats aground and after a few minutes the sea violently inundated the shore with very high waves, causing damage to the boats and some injured people. The sea water swept away the beach-umbrellas (Il Messaggero, 1978; Il Corriere Adriatico, 1978).

In many islands and places along the Yugoslavian coasts the sea water suddenly rose; at Vela Luka (Korcula island) the waves were $8 \mathrm{~m}$ high, inundating the first floors of all the buildings on the shore. Many ships suffered severe damage

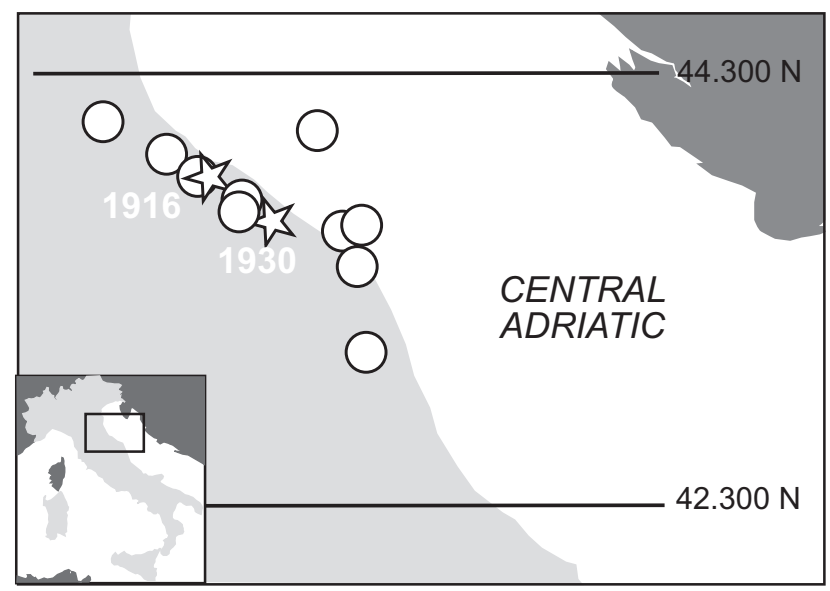

Fig. 4. Geographic distribution of the studied earthquakes in the central Adriatic subregion.

and the sea water flooded the cost by $650 \mathrm{~m}$ inland. Also at Cattaro (Montenegro), as well as at Dubrovnik and at the Vis island, anomalous waves were observed.

We notice further that, in spite of the fact that the event took place in modern instrumental era and affected a vast area, and that the Adriatic tides were monitored by a number of tide-gauge stations at the time, we were not able to find any instrumental records of this tsunami.

\section{Further tsunami events in central Adriatic}

In order to have a more complete picture of the tsunamigenic potential of the studied area, we performed accurate investigations on the earthquakes that occurred in the last century with the aim of identifying those potentially capable of generating tsunamis, also minor, that are not included in the Italian Tsunami Catalogue. To this purpose, all the available material was gathered, with a scrupulous and careful search for the sources, including specific monographs and scientific papers, articles available in contemporary chronicles and in national and local newspapers.

The first step of the analysis consisted in examining recent Italian seismic catalogues (Boschi et al., 1995, 1997; CPTI2, 2004) and selecting the most relevant earthquakes, with magnitude $M \geq 5.0$, in the geographical area included between latitude $42.300 \mathrm{~N}$ to $44.300 \mathrm{~N}$. We examined events occurred since 1900, with epicentre located in the sea or in land near the coast, namely not more than $25 \mathrm{~km}$ far from the shore. Thirteen significant earthquakes have been identified (Table 1 and Fig. 4.), and only for two of them tsunami evidences have been found, respectively the 16 August 1916 and the 1930 events.

The tsunami events have been examined by using the same evaluation parameters adopted during the Italian Tsunami 
Table 1. List of the studied earthquakes taken from the Italian catalogue CPTI2 (2004). In bold the two events for which tsunami evidences were found. For a definition of $\mathrm{M}_{e}$ see CPTI2 (2004).

\begin{tabular}{lcccl}
\hline Date & Latitude $\left(\mathrm{N}^{\circ}\right)$ & Longitude $\left(\mathrm{E}^{\circ}\right)$ & Magnitude $\left(\mathrm{M}_{e}\right)$ & Intensity $(\mathrm{MCS})$ \\
\hline 16 Nov 1908 & 43.155 & 13.596 & 5.4 & IV \\
19 Feb 1911 & 44.120 & 12.080 & 5.4 & VII \\
26 March 1911 & 44.061 & 12.507 & 5.2 & VII \\
17 May 1916 & 44.000 & 12.630 & 5.8 & VIII \\
16 Aug 1916 & $\mathbf{4 3 . 9 7 0}$ & $\mathbf{1 2 . 6 7 0}$ & $\mathbf{5 . 9}$ & VIII \\
5 Nov 1917 & 43.506 & 13.586 & 5.4 & VI \\
2 Jan 1924 & 43.736 & 13.141 & 5.6 & VII-VIII \\
30 May 1928 & 43.706 & 13.122 & 5.0 & V-VI \\
30 Oct 1930 & $\mathbf{4 3 . 6 5 9}$ & $\mathbf{1 3 . 3 3 1}$ & $\mathbf{5 . 9}$ & VIII-IX \\
30 Nov 1934 & 44.100 & 14.000 & 5.8 & V \\
23 Jan 1962 & 43.921 & 12.806 & 5.0 & VI \\
4 Feb 1972 & 43.633 & 13.550 & 5.2 & VIII \\
14 June 1972 & 43.650 & 13.600 & 5.4 & VIII \\
\hline
\end{tabular}

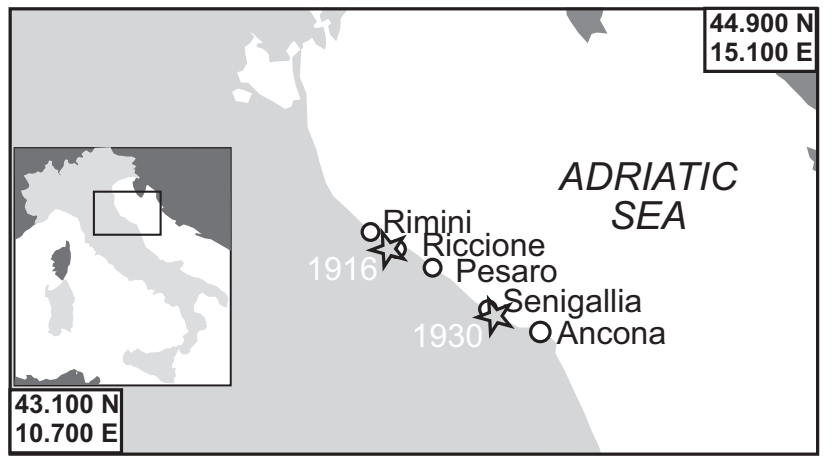

Fig. 5. Localities affected by the 1916 and 1930 tsunamis. Stars indicate the epicentres of the two shocks.

Catalogue compilation. Therefore each event is characterised by a reliability and a tsunami intensity value.

\subsection{August 1916 Rimini}

A long seismic sequence, that started on 17 May and lasted till December, caused disastrous damage at Rimini and in the neighboring villages (Fig. 5). The main shock occurred on 17 May, but the shock of 16 August (Mw=5.9 (CPTI2, 2004) I=VIII MCS scale) made worse the pre-existing damage and it was particularly strong at Rimini and Riccione and in the localities along the coast. At Rimini 4 victims and more than 60 injured people were counted. Descriptions of the tsunami effects are found in some newspapers where it was reported that during the shock of 16 August at Tavollo, close to Pesaro, small tsunami waves were observed (Corriere della Sera 17 August 1916; Gazzetta di Parma, 17 August 1916). Alfani (1916) and Boschi et al. (1997) also report the same description.
On the basis of the found information we attribute to this tsunami the highest reliability value 4 , that means "definite tsunami", and the tsunami intensity 2 "light" on the Ambraseys-Sieberg scale.

\subsection{October 1930 Senigallia}

This earthquake called "the Senigallia earthquake", with epicenter located on the coast, hit the coastal area in the central Adriatic, with maximum effects at Senigallia ( $\mathrm{Mw}=5.9$ (CPTI2, 2004), I=VIII-IX MCS scale) (Fig. 5). Here the shock caused severe damage with the total destruction of many buildings and 18 victims.

Boschi et al. (1995) mention a strong tsunami in the harbour of Ancona. The analysis of the contemporary newspapers gives a more detailed picture of the effects. They report that at Ancona a sudden high tide was noted and the sea boiled. An American steamship, moored in the "Molo della Sanità", broke its mooring because of the waves and it was slammed against the dock, suffering heavy damage. The railing of the harbour office was almost completely pulled off. The docks in the harbour were broken with large cracks. Many fishermen, that were on their ships in the harbour, quickly came back to the beach, frightened by the extraordinary movement of the water (Il Messaggero 31 October 1930; La Nazione 31 October 1930; Corriere Padano 31 October 1930).

Also to this event the highest reliability value 4 has been attributed and, on the basis of the description of the effects, the tsunami intensity is 4 "strong" on the Ambraseys-Sieberg scale. 


\section{Conclusions}

In this study we investigate all the potential tsunamigenic earthquakes occurred in the central Adriatic Sea since 1900. Among the thirteen examined earthquakes only two were followed by a tsunami. These events, that were not included in the Italian Tsunami Catalogue, are the 16 August 1916 Rimini event and the 30 October 1930 Senigallia event. These tsunamis were examined by following the catalogue guideline, therefore the present research is both a contribution for the updating of the catalogue itself and an improvement on the knowledge of the tsunamigenic potential of the central Adriatic region. As a result of this study, the number of tsunamis involving central Adriatic passes from three to five, and this increasing puts in evidence that a non-negligible hazard and risk related to tsunamis exist along the central Adriatic coasts. These coasts are characterised by flat and large beaches and the risk is especially high in the summer season, when the beaches and the water front resorts are crowded with tourists. We can also state that this region has the highest tsunamigenic potential among the whole Adriatic subregions, particularly for the number of occurred events, also taking into account that the analysis was limited only to the last century. Nevertheless, the results we obtained represent a valuable base for future tsunami modelling and hazard/risk assessment.

The next steps of this work will be the study of potential tsunamigenic earthquake occurred before 1900 and, in order to get a more complete knowledge of the tsunami activity of the whole Adriatic Sea, the events occurred on the Croatian, Albanian and Dalmatian coasts will be studied.

Edited by: E. Pelinovsky

Reviewed by: B. Ranguelov and another referee

\section{References}

Alfani, G.: Note ed Osservazioni sui terremoti della regione littoranea Adriatica nell'agosto 1916, Pubblicazioni dell'Osservatorio Ximeniano dei PP. Scolopi, n. 122, Firenze, 1916.

Altiner, Y., Marianovic, M., Medved, M., and Rasic, L.: Active Deformation of the Northern Adriatic Region: Results from the CRODYN Geodynamical Experiment, edited by: Pinter, N., Springer Verlag, ISBN 1402042345, 257-268, January 2006.

Ambraseys, N. N.: Data for investigation of seismic sea waves in the Eastern Mediterranean, Bull. Seism. Soc. Am., 52, 895-913, 1962.

Babbucci, D., Tamburelli, C., Viti, M., Mantovani, E., Albarello, D., D’Onza, F., Cenni, N., and Mugnaioli, E.: Relative motion of the Adriatic with respect to the confining plates: seismological and geodetic constraints, Geophys. J. Intern., 159, p.765, doi:10.1111/j.1365-246X.2004.02403, 2004.

Bada, G., Horvath, F., Gerner, P., and Fejes, I.: Review of the present-day geodynamics of the Pannonian basin: progress and problems, J. Geodynamics, 27(4), 501-527, 1999.
Battaglia, M., Murray, M. H., Serpelloni, E., and Bürgmann, R.: The Adriatic region: An independent microplate within the Africa-Eurasia collision zone, Geophys. Res. Lett., 31, L09605, doi:10.1029/2004GL019723, 2004.

Bedosti, B.: Considerazioni sul maremoto adriatico (tsunami) del 21.6.1978, Supplemento Bollettini Sismici Provv., 12-14-20, giugno, luglio, ottobre 1980, Osservatorio Meteorico-Sismico Valerio, Pesaro, 1980.

Boschi, E., Ferrari, G., Gasperini, P., Guidoboni, E., Smriglio, G., and Valensise, G.: Catalogo dei forti terremoti in Italia dal 461 a.C. al 1980, Istituto Nazionale di Geofisica - SGA Storia Geofisica Ambiente, Bologna, 1995.

Boschi, E., Guidoboni, E., Ferrari, G., Valensise, G., and Gasperini, P.: Catalogo dei forti terremoti in Italia dal 461 a.C. al 1990, Istituto Nazionale di Geofisica - SGA Storia Geofisica Ambiente, Bologna, 1997.

CPTI2 - Catalogo Parametrico dei Terremoti Italiani, versione 2 (CPTI04): INGV, Bologna, http://emidius.mi.ingv.it/CPTI, 2004.

CFTI - Catalogo dei Forti Terremoti Italiani: dal 461 a.C al 1997 Versione on-line, release 3,1. INGV-SGA, 2004.

Iida, K.: Earthquakes accompanied by tsunamis occurring under the sea off the islands of Japan, J. Earth Sci., Nagoya Univ., 4, 1-43, 1956.

Minisini, D., Trincardi, F., and Asioli, A.: Evidence of Slope Instability in the Southwestern Adriatic Margin, Nat. Hazards Earth Syst. Sci., 6, 1-20, 2006, http://www.nat-hazards-earth-syst-sci.net/6/1/2006/.

Muço, B.: Seismicity of the Adriatic Microplate and a Possible Triggering: Geodynamic Implication, edited by: Pinter, N., Springer Verlag, ISBN 1402042345, 351-368, January 2006.

Papadopoulos, G. A.: Seismic faulting and nonseismic tsunami generation in Greece, Proc. IUGG/IOC International Tsunami Symposium, 23-27 August, Wakayama, Japan, 1993, 115-122, 1993.

Pinter, N. and Grenerczy, G.: Recent advances in peri-Adriatic geodynamics and future research directions, edited by: Pinter, N., Springer Verlag, ISBN 1402042345, 1-20, January 2006.

Tinti, S., Maramai, A., and Graziani, L.: The new catalogue of Italian tsunamis, Nat. Hazards, 33, 439-465, 2004.

Thouvenot, F. and Fréchet, J.: Seismicity along the Northwestern Edge of the Adria Microplate, edited by: Pinter, N., Springer Verlag, ISBN 1402042345, 335-350, January 2006.

Trincardi, F., Cattaneo, A., Correggiati, A., and Ridente, D.: Evidence of soft sediment deformation, fluid escape, sediment failure and regional weak layers within the late Quaternary mud deposits of the Adriatic Sea, Mar. Geol., 213, 91-119, 2004.

Venisti, N., Calcagnile, G., Pontevivo, A., and Panza, G. F.: Tomographic Study of the Adriatic Plate, Pure Appl. Geophys., 162, 311-329, doi:10.1007/s00024-004-2602-6, 2005.

Zore-Armanda, M.: Tsunamis in the Adriatic, Pomorskog Zbornika, 26, 657-668, 1988.

\section{Newspapers}

Il Corriere Adriatico, Ancona, Year 1978, June 23.

Il Corriere della Sera, Milano, Year 1916, August 17.

Il Corriere Padano, Ferrara, Year 1930, October 31.

La Gazzetta di Parma, Parma, Year 1916, August 17.

Il Messaggero, Roma, Year 1930, October 31.

Il Messaggero, Roma, Year 1978, June 23.

La Nazione, Firenze, Year 1930, October 31. 